\title{
Inclusion Setting for Disabilities in Higher Education: A Systematic Review of Issues and Challenges in Disabilities Research
}

\author{
Syed Muhammad Rafy Syed Jaafar* 1,5, Rosnizam Maarof ${ }^{2,5}$, Muhammad \\ Juzaili Hisam ${ }^{3,5}$, Nik Nor Farah Annysa Husin ${ }^{4,5}$ \\ ${ }^{1}$ Faculty of Built Environment and Surveying, Universiti Teknologi Malaysia \\ ${ }^{2}$ School of Professional and Continuing Education, Universiti Teknologi Malaysia \\ ${ }^{3}$ School of Mechanical Engineering, Faculty of Engineering, Universiti Teknologi Malaysia \\ ${ }^{4}$ School of Computing, Faculty of Engineering, Universiti Teknologi Malaysia \\ ${ }^{5}$ Kolej Tun Razak, Universiti Teknologi Malaysia \\ *Corresponding Author Email: s.rafy@utm.my
}

\begin{abstract}
Department of Higher Education Malaysia has launched the guideline that emphasis on disabilities to promote inclusivity setting at higher education institutions. The idea is basically to highlighted the effort by leaving no one behind. Nowadays, students with disabilities facing many challenges and hardships to adapt and adopt with the current institutions setting including physical and non-physical aspects. This paper intended to do a systematic review of the disabilities research for the past 20 years. The information and knowledge of this review are believed to help in assisting the higher education institutions providing a more comprehensive environment for the disable students which later helps them persist and remain in the institution.
\end{abstract}

Keywords: Disabilities, Higher Education, Inclusion

\section{INTRODUCTION}

It is possible to refer to inclusion as having allencompassing access to classes and physical spaces that include programmes, enrolment, and activities within the university environment [1]. The social movement to participate in people with disabilities has kept increasing which now becoming a cornerstone for social policy and the voice for them to has better equality [2]. In Malaysia, however, the trend began in the 1960s, when an introduction of community-based rehabilitation programmes was proposed by the Malaysian Ministry of Health to change from custodial care to deindustrialisation. This effort is defined as a failure because, from the viewpoint of the provider, people with disabilities were seen as engaging in decision-making, policymaking, resource allocation, and service provision instead of users [3]. The Malaysian government took a step forward in implementing and rectifying the Individual with Disabilities Act during the Incheon Strategies to Make Rights Meaningful for People with Disabilities in 2008. This dedication demonstrated the seriousness of Malaysia in achieving the rights of people with disabilities while enhancing the quality of their lives.

\section{OVERVIEW ON THE ISSUE AND CHALLENGES OF DISABILITIES IN HIGHER EDUCATION (HE)}

There are many issues and challenges experienced by students with disabilities in HE despite the efforts made by the Governments. Some of the difficulties faced by students with disabilities are due to their institutions' conventional criteria, such as 'fitness' to perform duties. This is one of HE's difficulties in embracing students with extreme mobility, vision, voice, or hearing impairments related to health courses [4]. Nevertheless, after they completed their studies and began working, students with disabilities have encountered difficulties where their employers could have negative thoughts about their ability to work [5] as well as their participation rates and earnings [6,7]. [8] also addressed this issue where they stated that employers typically had no concerns with people with a physical impairment or moderate impairment, or were not interested in emotional or more complex disabilities. In particular, several researchers have also emphasised that the internal challenge for students with disabilities to seek further education in higher institutions and jobs is due to side effects of medication, lack of personal motivation and physical 
health concerns after they completed their secondary school $[9,10,11]$. With increasing concerns and the number of students with disabilities enrolled in HE institutions, the notion of inclusiveness is required. This is to guarantee that these segments have not been left behind and that the goal of achieving inclusive education is a success.

\section{1 'Leaving No One Behind': The efforts done by the Higher Education (HE) in Malaysia to Support Sustainable Development Goals (SDGs)}

Inclusive education must be seen as a platform for wellbeing, educational equity, and capability of these students in the realisation of inclusivity in HE for students with disabilities [12]. The pledge to 'leaving no one behind' is one of the initiatives that has been highlighted in the Sustainable Development Goals (SDGs) in which to advance inclusive development for all. It also highlighted that the societies will never achieve the SDGs without the full involvement of everybody together with persons with disabilities. UN
Secretary-General Antonio Guterres added that the contributions of 1.5 billion people could not be ignored or marginalized. He also added that many countries are yet still lacking in the provision of essential services for persons with disabilities, especially those with poverty background. Apart from that, it is also important in making sure that persons with disabilities are visible in policymaking especially when it comes to education. The need to recognise persons with disabilities and their potential as contributors to society is vital to enhance the current efforts and rights in achieving inclusivity at all levels. And for now, however, in Malaysia the number of people with disabilities is not complete because registering them is not legally mandatory. This is also agreed by [13] where they mentioned that due to the non-updated data several challenges had occurred especially among the service providers and users itself. Nevertheless, as shown in Table 1, statistics from the Ministry of Education (MoE) indicate a steady growth in the number of students with disabilities at Malaysian public universities, although there is a small decrease in enrolment between 2017 and 2018 .

Table 1: Undergraduate students' enrolment in public higher education institution from 2014 to 2018 (MOE, 20142018).

\begin{tabular}{|c|c|c|}
\hline Year & Total Enrolment (Bachelor) & Students with Disabilities Enrolment \\
\hline $\mathbf{2 0 1 4}$ & 340,538 & 1742 \\
\hline $\mathbf{2 0 1 5}$ & 324,894 & 1930 \\
\hline $\mathbf{2 0 1 6}$ & 322,507 & 2444 \\
\hline $\mathbf{2 0 1 7}$ & 332,023 & 2139 \\
\hline $\mathbf{2 0 1 8}$ & 338,563 & 1874 \\
\hline
\end{tabular}

It is indisputable that education plays significant role in the progress of both individuals and the country. This is because education is not only vital to the growth of academic and personal quality, it is also an important factor in the potential for jobs. [14] clarify that people with disabilities also need the education to enable them not only to read and write but also involved in a more complex environment such as in decision making and finding a job. Additionally, he also mentioned that with education, people with disabilities can acquire a better life, respect by others, and also gain interpersonal skills. "Due to these factors, the philosophy of the academic world has moved from "disciplinary research" to "pedagogical research" [15]. In acknowledging the value of inclusive education, [12] said that inclusive education would serve as a mechanism for equity in education, equity of skills, fairness, and the well-being of students with disabilities. Not only that, all related services and programmes should also be implemented and improved to ensure that children with disabilities can be integrated into society, such as community-based intervention programmes, initiatives for teacher development, inclusive schools, and education facilitation programmes [16]). Despite having regional instruments and international, such as ASEAN declarations and UN conventions, developing countries such as Malaysia still face some difficulties in implementing comprehensive and equitable education for children with disabilities. The reasons behind these issues are due to the mistranslation of the theory of education for children with disabilities, various agencies' inconsistent definitions of disability, and discriminatory policies [17]. Hence, the existence of every instrument and strategies whether it is global or regional needs to be treated and adopted properly in the local context to ensure those tools do not function as a nice book on the bookshelf. 


\section{METHODOLOGY}

In terms of methodology, the author conducted a systematic review by gathering and analysing papers that were published online for the past 20 years related to disabilities research in higher education from various sources. From the year 2000 until 2019, the author analysed 19 papers from 12 different reputable journals that mainly focused on issues and challenges related to disabilities research or study. The articles used for the study were gathered through SAGE, ProQuest, Science Direct, and Emerald Sight platform through the systematic review process (SLR) as proposed by [18].
The trends in the publication that is related to disabilities research in higher education from the year 2000 until 2019 were shown in Figure 1 below. In continuity of the process, the critical literature content has been done to understand the gap arises on the disability research from the 19 papers. The gap can be seen through the key findings and variables that been found by the al the authors in the last 20 years.

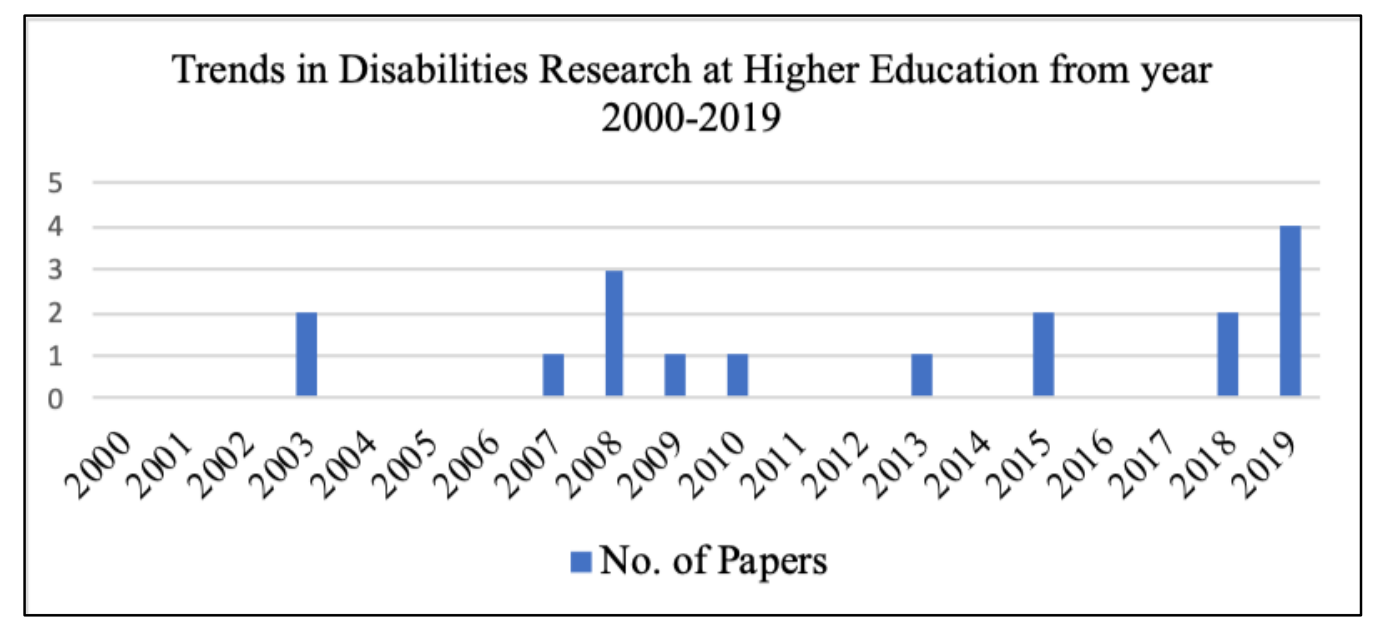

Figure 1: Summary of trends in publication related with disabilities research in higher education from the year 2000 until 2019

\section{FINDINGS AND DISCUSSION}

In general, the importance of disability studies and its relationship with higher education perspective is vital, especially within the Malaysian context. This is to ensure that better protection and awareness of students with disabilities can be implemented either through the enhancement of physical aspect, academician or through their curricular activities. Additionally, disability studies have also become a crucial and important discipline due to its complexities regarding issues and challenges involving disabled people [19]. In Malaysia, the increasing cases shows that there is a need for the government and respective agencies to highlight their needs once they step into the institution of higher education. With that in mind, studies on disability should be done progressively in order to get ideas and sufficient information on their needs in higher education level. Table 2 shows the articles on the disabilities research for 2000 to 2019 .

Table 2: Articles on the disabilities research for 2000 to 2019

\begin{tabular}{|l|l|l|l|l|}
\hline Year & Author(s) & Title & Journal & Key Research Findings \\
\hline $\mathbf{2 0 0 3}$ & $\begin{array}{l}\text { McLaughlin } \\
\text { et al. [20] }\end{array}$ & $\begin{array}{l}\text { Educational accountability and } \\
\text { students with disabilities: Issues and } \\
\text { challenges. }\end{array}$ & $\begin{array}{l}\text { Educational } \\
\text { Policy }\end{array}$ & $\begin{array}{l}\text { New accountability } \\
\text { requirements which focused } \\
\text { on system compliance with } \\
\text { procedures. }\end{array}$ \\
\hline $\mathbf{2 0 0 3}$ & $\begin{array}{l}\text { Heiman \& } \\
\text { Precel [21] }\end{array}$ & $\begin{array}{l}\text { Students with learning disabilities in } \\
\text { higher education: Academic } \\
\text { strategies profile. }\end{array}$ & $\begin{array}{l}\text { Journal of } \\
\text { learning } \\
\text { disabilities }\end{array}$ & $\begin{array}{l}\text { Academic difficulties, } \\
\text { learning strategies and } \\
\text { factors that help academic } \\
\text { success }\end{array}$ \\
\hline $\begin{array}{l}\text { Rajohane } \\
\text { Matshedisho }\end{array}$ & $\begin{array}{l}\text { Access to higher education for } \\
\text { disabled students in South Africa: a } \\
\text { contradictory conjunction of } \\
\text { benevolence, rights and the social } \\
\text { model of disability. }\end{array}$ & $\begin{array}{l}\text { Disability \& } \\
\text { Society }\end{array}$ & $\begin{array}{l}\text { Disability rights, political } \\
\text { commitment and legacy of } \\
\text { benevolence }\end{array}$ \\
\hline
\end{tabular}




\begin{tabular}{|c|c|c|c|c|}
\hline 2008 & Getzel [23] & $\begin{array}{l}\text { Addressing the persistence and } \\
\text { retention of students with disabilities } \\
\text { in higher education: Incorporating } \\
\text { key strategies and supports on } \\
\text { campus. }\end{array}$ & Exceptionality & $\begin{array}{l}\text { Self-determination skills, } \\
\text { assistive technologies, } \\
\text { career development }\end{array}$ \\
\hline 2008 & $\begin{array}{l}\text { Sharma et } \\
\text { al. [24] }\end{array}$ & $\begin{array}{l}\text { Impact of training on pre-service } \\
\text { teachers' attitudes and concerns } \\
\text { about inclusive education and } \\
\text { sentiments about persons with } \\
\text { disabilities. }\end{array}$ & $\begin{array}{l}\text { Disability \& } \\
\text { Society }\end{array}$ & $\begin{array}{l}\text { Attitudes, sentiments and } \\
\text { concerns, teacher self- } \\
\text { efficacy }\end{array}$ \\
\hline 2008 & $\begin{array}{l}\text { Denhart } \\
{[25]}\end{array}$ & $\begin{array}{l}\text { Deconstructing barriers: Perceptions } \\
\text { of students labelled with learning } \\
\text { disabilities in higher education. }\end{array}$ & $\begin{array}{l}\text { Journal of } \\
\text { Learning } \\
\text { Disabilities } \\
\end{array}$ & $\begin{array}{l}\text { Raising faculty awareness, } \\
\text { engaging assistance and } \\
\text { democratic empowerment }\end{array}$ \\
\hline 2009 & $\begin{array}{l}\text { Winn \& } \\
\text { Hay [6] }\end{array}$ & $\begin{array}{l}\text { Transition from school for youths } \\
\text { with a disability: Issues and } \\
\text { challenges. }\end{array}$ & $\begin{array}{l}\text { Disability \& } \\
\text { Society }\end{array}$ & $\begin{array}{l}\text { Transition planning } \\
\text { approach, quality of service } \\
\text { provision and inequality of } \\
\text { vocational transition }\end{array}$ \\
\hline 2010 & $\begin{array}{l}\text { Vickerman } \\
\text { \& Blundell } \\
{[26]}\end{array}$ & $\begin{array}{l}\text { Hearing the voices of disabled } \\
\text { students in higher education. }\end{array}$ & $\begin{array}{l}\text { Disability \& } \\
\text { Society }\end{array}$ & $\begin{array}{l}\text { Facilitate barrier free } \\
\text { curricula and embedding of } \\
\text { personal development } \\
\text { planning }\end{array}$ \\
\hline 2013 & $\begin{array}{l}\text { Mullins \& } \\
\text { Preyde [27] }\end{array}$ & $\begin{array}{l}\text { The lived experience of students with } \\
\text { an invisible disability at a Canadian } \\
\text { university. }\end{array}$ & $\begin{array}{l}\text { Disability \& } \\
\text { Society }\end{array}$ & $\begin{array}{l}\text { Invisible disability, } \\
\text { organisation barriers and } \\
\text { nature of disability }\end{array}$ \\
\hline 2015 & $\begin{array}{l}\text { Plotner \& } \\
\text { Marshall } \\
{[28]}\end{array}$ & $\begin{array}{l}\text { Postsecondary education programs } \\
\text { for students with an intellectual } \\
\text { disability: Facilitators and barriers to } \\
\text { implementation. }\end{array}$ & $\begin{array}{l}\text { Intellectual and } \\
\text { developmental } \\
\text { disabilities }\end{array}$ & $\begin{array}{l}\text { Initial barrier in intellectual } \\
\text { disability program } \\
\text { development. }\end{array}$ \\
\hline 2015 & $\begin{array}{l}\text { Milic Babic } \\
\& \text { Dowling } \\
{[29]}\end{array}$ & $\begin{array}{l}\text { Social support, the presence of } \\
\text { barriers and ideas for the future from } \\
\text { students with disabilities in the } \\
\text { higher education system in Croatia. }\end{array}$ & $\begin{array}{l}\text { Disability \& } \\
\text { Society }\end{array}$ & $\begin{array}{l}\text { Equality of opportunity in } \\
\text { HE, disability awareness for } \\
\text { academics }\end{array}$ \\
\hline 2017 & $\begin{array}{l}\text { Heiman et } \\
\text { al. [30] }\end{array}$ & $\begin{array}{l}\text { Access and perceived ICT usability } \\
\text { among students with disabilities } \\
\text { attending higher education } \\
\text { institutions. }\end{array}$ & $\begin{array}{l}\text { Education and } \\
\text { Information } \\
\text { Technologies }\end{array}$ & $\begin{array}{l}\text { Difficulties in coping with } \\
\text { academic skills using ICT }\end{array}$ \\
\hline 2017 & Morina [31] & $\begin{array}{l}\text { Inclusive education in higher } \\
\text { education: challenges and } \\
\text { opportunities. }\end{array}$ & $\begin{array}{l}\text { European } \\
\text { Journal of } \\
\text { Special Needs } \\
\text { Education }\end{array}$ & $\begin{array}{l}\text { Opportunities in inclusive } \\
\text { education, designing } \\
\text { policies for inclusive } \\
\text { settings }\end{array}$ \\
\hline 2018 & $\begin{array}{l}\text { Hove et al. } \\
{[32]}\end{array}$ & $\begin{array}{l}\text { Students with disabilities in higher } \\
\text { education. }\end{array}$ & Social Inclusion & Inclusive education in $\mathrm{HE}$ \\
\hline 2018 & $\begin{array}{l}\text { Pacheco et } \\
\text { al. [33] }\end{array}$ & $\begin{array}{l}\text { Transition 2.0: Digital technologies, } \\
\text { higher education, and vision } \\
\text { impairment. }\end{array}$ & $\begin{array}{l}\text { The Internet and } \\
\text { Higher } \\
\text { Education }\end{array}$ & $\begin{array}{l}\text { Technology implementation } \\
\text { in disabilities transition to } \\
\mathrm{HE}\end{array}$ \\
\hline 2019 & $\begin{array}{l}\text { Los Santos } \\
\text { et al. [34] }\end{array}$ & $\begin{array}{l}\text { Determining Academic Success in } \\
\text { Students with Disabilities in Higher } \\
\text { Education. }\end{array}$ & $\begin{array}{l}\text { International } \\
\text { Journal of } \\
\text { Higher } \\
\text { Education }\end{array}$ & $\begin{array}{l}\text { Relationship between } \\
\text { university's facilities and } \\
\text { services in determining the } \\
\text { student with disabilities } \\
\text { academics success. }\end{array}$ \\
\hline 2019 & $\begin{array}{l}\text { Yusof et al. } \\
{[4]}\end{array}$ & $\begin{array}{l}\text { Improving inclusion of students with } \\
\text { disabilities in Malaysian higher } \\
\text { education. }\end{array}$ & $\begin{array}{l}\text { Disability \& } \\
\text { Society }\end{array}$ & $\begin{array}{l}\text { Opportunity to HE access, } \\
\text { central role of university }\end{array}$ \\
\hline 2019 & $\begin{array}{l}\text { Zainal \& } \\
\text { Hashim [35] }\end{array}$ & $\begin{array}{l}\text { The Implementation of Transition } \\
\text { Programme for Students with } \\
\text { Learning Disabilities in Malaysia. }\end{array}$ & $\begin{array}{l}\text { Creative } \\
\text { Education }\end{array}$ & $\begin{array}{l}\text { Career transition, } \\
\text { importance of 3C's } \\
\text { (Collaboration, } \\
\text { Communication and } \\
\text { Community) }\end{array}$ \\
\hline 2019 & $\begin{array}{l}\text { Nasir \& } \\
\text { Efendi [36] }\end{array}$ & $\begin{array}{l}\text { Thematic analysis on the rights of } \\
\text { disabled people to higher education. }\end{array}$ & $\begin{array}{l}\text { Journal of } \\
\text { Education and } \\
\text { Social Sciences }\end{array}$ & $\begin{array}{l}\text { Building alliance, } \\
\text { establishment of disability } \\
\text { emancipation climate }\end{array}$ \\
\hline
\end{tabular}


While the above argument has the potential to make gradual changes in disability studies, it also has the potential to reconsider all aspects of the study process by considering a universal study design[37]. The inclusion in the design process of the experiences of students with disabilities would potentially enable researchers to create more variant instruments, generate and increase interest in participation, and also represent findings that could better enhance the experiences of students with disabilities. [38] in their study also highlighted that universal design has become a common part of classroom instruction where researchers can take into account its principles to ensure that data collection instruments are fully accessible. Through this process, students with disabilities were not only acting as passive conveyors but actively involved in multiple phases of the academics process. It is suggested that students with disabilities should benefit from their participation in the study be it in the classroom or doing their curricular activities. The findings also identified the gaps that lie between the lived experiences of students with disabilities and what they value in higher education. In general, issues such as mutual respect should be taken into accounts such as in terms of mobility inter and intra university and the usability of physical spaces. In ensuring equal skills and well-being for all students, in particular for those with disabilities, these factors should be well addressed by disability services in HE. In addition, although the academic staff is attempting to make changes for tests, teaching experiences are often crucial through tutoring services help.

\section{CONCLUDING THOUGHTS}

Although the discussion regarding disability is not a new one in higher education, and urgency rises to undergo rigorous research in order to portray a better perspective towards policy and practices in HE where the emergence of the student with disabilities is growing as their number in university intakes keep in increasing. The author hopes that this paper attempted in providing the HE community the outline of research and basic information related to disabilities in HE, with a specific focus on the key findings of the previous research is achieved. This paper intended to initiate and suggest possible ways in expanding the existing theories and models of higher education students, environments, and processes that can be further used in developing a guideline that can be implemented especially in HE. The effort is plausible by focusing on research regarding access pathways, learning outcomes, transition, and Universal Design that will have an immediate practical benefit to both the research community and students with disabilities.

As a first step towards greater diversity and inclusion in higher education, this situation will spark a new and greater understanding of disabilities, the organisations that seek to serve them, and the research methods needed to authentically reflect their experiences. In conclusion, Malaysia has certainly seen a strong trend in the provision of quality education for children and adolescents with disabilities. However, the respective agencies and stakeholders, as well as the Ministry of Higher Education, academician, and university management, still have problems and challenges to face. These include unstructured services, inadequate infrastructure and accessibility to technology, financial constraints, low preparation among special and general educators, and self-conflict among individuals. Furthermore, recognising these challenges will empower those responsible to effectively prepare, execute, track, and assess the measures taken to achieve inclusiveness for students with disabilities, especially at the HE level.

\section{ACKNOWLEDGMENT}

The authors would like to extend their appreciation to the Universiti Teknologi Malaysia for the funded given under Fundamental Research Grant Scheme 5F213 (The demand of Disable and Grey Tourists in effectuate the Tourism for All in Urban Destination) that make this paper possible.

\section{REFERENCES}

[1] Singh, N. N., Lancioni, G. E., Karazsia, B. T., Winton, A. S., Myers, R. E., Singh, A. N., ... \& Singh, J. (2013). Mindfulness-based treatment of aggression in individuals with mild intellectual disabilities: A waiting list control study. Mindfulness, 4(2), 158-167.

[2] Gravel, B. E., \& Wilkerson, M. H. (2017). Integrating computational artifacts into the multirepresentational toolkit of physics education. In Multiple representations in physics education (pp. 47-70). Springer, Cham.

[3] Jayasooria, D., \& Ooi, G. (1994). Disabled peoples movement in Malaysia. Disability \& Society, 9(1), 97-100.

[4] Yusof, Y., Chan, C. C., Hillaluddin, A. H., Ahmad Ramli, F. Z., \& Mat Saad, Z. (2019). Improving inclusion of students with disabilities in Malaysian higher education. Disability \& Society, 1-26.

[5] Kidd, M. P., Sloane, P. J., \& Ferko, I. (2000). Disability and the labour market: an analysis of British males. Journal of health economics, 19(6), 961-981.

[6] Winn, S., \& Hay, I. (2009). Transition from school for youths with a disability: Issues and challenges. Disability \& Society, 24(1), 103-115.

[7] Montgomery, D. J., \& Marks, L. J. (2006). Using technology to build independence in writing for students with disabilities. Preventing School Failure: Alternative Education for Children and Youth, 50(3), 33-38. 
[8] Johnson, K. P., Brooks, B. R., Cohen, J. A., Ford, C. C., Goldstein, J., Lisak, R. P., ... \& Vollmer, T. (1998). Extended use of glatiramer acetate (Copaxone) is well tolerated and maintains its clinical effect on multiple sclerosis relapse rate and degree of disability. Neurology, 50(3), 701708 .

[9] Braitman, A., Counts, P., Davenport, R., Zurlinden, B., Rogers, M., Clauss, J., ... \& Montgomery, L. (1995). Comparison of barriers to employment for unemployed and employed clients in a case management program: An exploratory study. Psychiatric Rehabilitation Journal, 19(1), 3.

[10] Mowbray, C. T., Bybee, D., Harris, S. N., \& McCrohan, N. (1995). Predictors of work status and future work orientation in people with a psychiatric disability. Psychiatric Rehabilitation Journal, 19(2), 17.

[11] Pilling, D. S. (2002). Early employment careers of people with disabilities in the National Child Development Study. Work, 18(1), 75-87.

[12] Terzi, R., \& Altın, F. (2014). Examination of the patient's locomotor system disability evaluated in the board of health for disabled. Turkish Journal of Osteoporosis, 20, 60-4.

[13] Page, S. L., \& Islam, M. R. (2015). The role of personality variables in predicting attitudes toward people with intellectual disability: An A ustralian perspective. Journal of Intellectual Disability Research, 59(8), 741-745.

[14] Singal, N., Mahama Salifu, E., Iddrisu, K., CaselyHayford, L., \& Lundebye, H. (2015). The impact of education in shaping lives: Reflections of young people with disabilities in Ghana. International Journal of Inclusive Education, 19(9), 908-925.

[15] Vulliamy, G., \& Webb, R. (1993). Special educational needs: From disciplinary to pedagogic research. Disability, Handicap \& Society, 8(2), 187-202.

[16] Al-Obaidi, A., \& Budosan, B. (2011). Mainstreaming educational opportunities for physically and mentally disabled children and adolescents in Iraq. Advances in School Mental Health Promotion, 4(1), 35-43.

[17] Adnan, A. H., \& Hafiz, I. A. (2001). A disabling education: The case of disabled learners in Malaysia. Disability \& Society, 16(5), 655-669.

[18] Denyer, D., \& Tranfield, D. (2008). Producing a systematic review. In D. A. Buchanan \& A. Bryman (Eds.), The Sage handbook of organizational research
[19] Shakespeare, T. (Ed.). (2015). Disability research today: International perspectives. Routledge.

[20] McLaughlin, M. J., \& Thurlow, M. (2003). Educational accountability and students with disabilities: Issues and challenges. Educational Policy, 17(4), 431-451.

[21] Heiman, T., \& Precel, K. (2003). Students with learning disabilities in higher education: Academic strategies profile. Journal of learning disabilities, 36(3), 248-258.

[22] Rajohane Matshedisho, K. (2007). Access to higher education for disabled students in South Africa: a contradictory conjuncture of benevolence, rights and the social model of disability. Disability \& Society, 22(7), 685-699.

[23] Getzel, E. E. (2008). Addressing the persistence and retention of students with disabilities in higher education: Incorporating key strategies and supports on campus. Exceptionality, 16(4), 207219.

[24] Sharma, U., Forlin, C., \& Loreman, T. (2008). Impact of training on pre-service teachers' attitudes and concerns about inclusive education and sentiments about persons with disabilities. Disability \& Society, 23(7), 773-785.

[25] Denhart, H. (2008). Deconstructing barriers: Perceptions of students labeled with learning disabilities in higher education. Journal of Learning Disabilities, 41(6), 483-497.

[26] Vickerman, P., \& Blundell, M. (2010). Hearing the voices of disabled students in higher education. Disability \& Society, 25(1), 21-32.

[27] Mullins, L., \& Preyde, M. (2013). The lived experience of students with an invisible disability at a Canadian university. Disability \& Society, 28(2), 147-160.

[28] Plotner, A. J., \& Marshall, K. J. (2015). Postsecondary education programs for students with an intellectual disability: Facilitators and barriers to implementation. Intellectual and developmental disabilities, 53(1), 58-69.

[29] Milic Babic, M., \& Dowling, M. (2015). Social support, the presence of barriers and ideas for the future from students with disabilities in the higher education system in Croatia. Disability \& Society, 30(4), 614-629.

[30] Heiman, T., Fichten, C. S., Olenik-Shemesh, D., Keshet, N. S., \& Jorgensen, M. (2017). Access and perceived ICT usability among students with disabilities attending higher education 
institutions. Education and Information Technologies, 22(6), 2727-2740.

[31] Morina, A. (2017). Inclusive education in higher education: challenges and opportunities. European Journal of Special Needs Education, 32(1), 3-17.

[32] Hove, G. V., Schippers, A., \& Bakker, M. (2018). Students with disabilities in higher education. Social Inclusion, 6(4), 103-106.

[33] Pacheco, E., Lips, M., \& Yoong, P. (2018). Transition 2.0: Digital technologies, higher education, and vision impairment. The Internet and Higher Education, 37, 1-10.

[34] Los Santos, D., Bain, S., Kupczynski, L., \& Mundy, M. A. (2019). Determining Academic Success in Students with Disabilities in Higher Education. International Journal of Higher Education, 8(2), 16-38.
[35] Zainal, M. S., \& Hashim, H. (2019). The Implementation of Transition Programme for Students with Learning Disabilities in Malaysia. Creative Education, 10(8), 1802-1812.

[36] Nasir, M. N. A., \& Efendi, A. N. A. E. (2019). Thematic analysis on the rights of disabled people to higher education. Journal of Education and Social Sciences, 12(1), 8-17.

[37] Vaccaro, A., Daly-Cano, M., \& Newman, B. M. (2015). A sense of belonging among college students with disabilities: An emergent theoretical model. Journal of College Student Development, 56(7), 670-686.

[38] Hackman, H. W., \& Rauscher, L. (2004). A pathway to access for all: Exploring the connections between universal instructional design and social justice education. Equity \& Excellence in Education, 37(2), 114-123. 